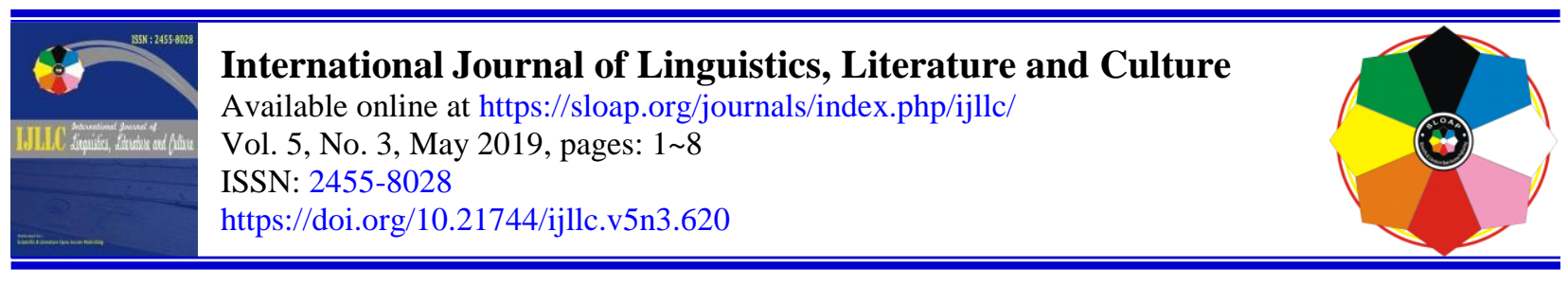

\title{
Nyorat Ceremony of Hindu Kaharingan Adherents: Telawang District, East Kotawaringin Regency
}

Article history:

Received: 27 January 2019

Accepted: 31 March 2019

Published: 1 May 2019

\section{Keywords:}

nyorat;

ceremony;

hindu;

kaharingan;

telawang;

\begin{abstract}
The result of the study covers all three aspects. First, the causes of the Nyorat ceremony are held after thirty days of dead body to be lied down in the funeral house: (1) The belief factor of the spirit of the deceased person, (2) the fear factor for the unfortunate (3) religious social factor, (4) the economic factor of the Kaharingan Hindu adherents, and (5) the factor of affection towards the ancestral spirit of the late. The last factor is based on the assumptions, namely (1) preparing the Nyorat ceremonial facilities and infrastructure, (2) it is not to lose the meaning that can be inherent in it, (3) to purify/cleanse the spirit of the dead so that the sacred and inner and family will get happiness back. The implications of the Nyorat ceremony are (1) the religious implications relating to the belief of the Hindu Kaharingan adherents from generation to generation, that if they are not implemented, they will lose the meaning of the Nyorat ceremonial purposes, (2) the psychological implications require cooperation, (3) the social implications culture is the act of intervening to support the course of the ceremony, and (4) the economic implications of the community strongly support the course of the ceremony. Based on the results of the analysis, it is obtained three things. The first is the reasons of the Hindu adherents to conduct the Nyorat ceremony, the second is processes of implementation of the Nyorat ceremony, the three religious, psychological, and social implications, and the community's economy towards the Hindu Kaharingan religious system are acceptable to the local community.
\end{abstract}

2455-8028 ${ }^{\circ}$ Copyright 2019. The Author. This is an open-access article under the CC BY-SA license (https://creativecommons.org/licenses/by-sa/4.0/) All rights reserved.

\section{Author correspondence:}

Riwun,

Institut Agama Hindu Negeri Tampung Penyang Palangka Raya, Indonesia.

Email: riwunriwun079@gmail.com

a Institut Agama Hindu Negeri Tampung Penyang Palangka Raya, Indonesia

${ }^{\mathrm{b}}$ Universitas Hindu Indonesia, Denpasar, Bali

${ }^{\mathrm{c}}$ Universitas Hindu Indonesia, Denpasar, Bali 


\section{Introduction}

The Nyorat ceremonies are very important to be investigated because the aim is to free oneself from pesky/ambun rutas matei which is caused by deaths among families which cause grief for the family so that the loss of harmony in life will be disturbed and there is no balance. This must be removed from the family by carrying out the Nyorat ceremony so that the balance and harmony can return as usual for the close family of the deceased.

By looking at the purpose of the Nyorat ceremony and being the background for carrying out the Nyorat ceremony the main purpose is (1) delivering spirits/liau people who have died in the hilly pasahan raung grave/pambak. (2) Purifying the family from the pesky/ambun rutas matei due to death in addition to the family will be released and get peace and balance again. The state of grief makes the heart/feelings of the family shaken so that they feel disturbed in activities outside the house including worshiping God. This uncertain feeling that must be expelled, removed from within the household family members through the Nyorat ceremony. The Nyorat ceremony function for the family is (1) The spirit/liau the deceased knows its existence as a spirit. (2) After completion, it is hoped that the bereaved family will get a balanced and harmonious environment. Furthermore, family members can return to their normal activities (Ruda, 2005).

The focus of this study was the Nyorat ceremony held by Hindu Kaharingan in Sebabi Village, Telawang District, East Kotawaringin Regency. The word Nyorat comes from the Ot Danum language which means the ritual of death. The Nyorat ceremony was held in Sebabi village with a system of mutual cooperation between the environmental community, for example working together mourning to the funeral home, telling stories of sharing experiences and life problems or just chatting every night to the deceased's closest family.

Adi (2008) \& Rahmawati, (2008), the uniqueness attracts researchers to understand the reason for holding a Nyorat ceremony even by laying down a body thirty days in a funeral home. The aim of the researchers is to be able to understand and explain to the general public about the procedures for implementing the Nyorat ceremony and the religious, economic and psychological implications for the surrounding community. This is important because no one has conducted research on Nyorat ceremonies. This means that there is no detailed explanation of the meaning, meaning, and implications of the Nyorat. This view reflects that all human activities related to religion are based on a mental vibration called religious emotion. Religious emotion also animates the belief system which is revealed through mythology in the society which is closely related to rites and ceremonies.

\section{Materials and Methods}

Based on Van Gennep's assumptions of the Theory of Religion, it discusses transitional rites or rituals in people's lives. Ceremonies have a protective function for the community as a whole and reduce the influence that is not good from the group's journey, role or status. Van Gennep identifies the internal structure of the transitional ceremony into three phases, namely rite of separation (rites of separation), threshold rites (pf threshold rite), and aggregation rites (rite of aggregation). In accordance with the above, the Nyorat ceremony for Kaharingan Hindus needs to be studied and applied in addition to it is also a way for them to be able to express respect and love to the spirit of someone who has died by their family either through words or deeds and done with sadness and sincerity so that someone can free himself from debt and be able to pay it to the spirits of the ancestors of parents or families who have died. The phenomenon attracts the attention of researchers to understand, understand, and examine the reasons for laying a dead body for thirty days in a funeral home, in order to understand the procedure of implementation and to examine the religious, psychological, social cultural and economic implications of the Nyorat ceremony on Kaharingan Hindus in the Regency Kotawaringin Timur.

\section{Results and Discussions}

Kaler (1993) \& Dhavamony (1995), the Nyorat ceremony is a series of death ceremonies carried out by Hindus Kaharingan in Sebabi Village, Telawang District, East Kotawaringin Regency. The word Nyorat comes from the language of Danum which means the ceremony of death. In Indonesian, it means something lifeless or not breathing. This is because in the understanding of the Kaharingan a person if someone does not breathe means he has died. With the existence of death means the separation between the spirit of the deceased person and the spirit of his 
family who is still alive, so that both of them can carry out their respective lives do not disturb each other. This can be done by the Kaharingan people by carrying out the Nyorat ceremony.

The purpose of the Nyorat ceremony is to theoretically try to give a comprehensive and clear picture of the reason for the death of the body for thirty days in the funeral home. Besides that, it can also add to the treasure of religious knowledge, especially about the ritual system of the Hindu Kaharingan community which has been inherited from generation to generation, which can be morally justified. Practically, it can provide clear information in the form of new knowledge to Hindu Kaharingan in Katawaringin Timur regarding the concept of trust, corpses must be buried, this is important to anticipate the loss of meaning, and to change the meaning of culture. The results of this study also motivated and directed youth mobilization to continue to love, maintain and further study in order to remain everlasting and useful for Kaharingan Hindus.

There are several expert opinions to define theories, such as religious theory, functionalism theory and reception theory as supporters of the problem. Religious theory is a form or method by Kaharingan Hindus to offer something to the souls of someone who has died. Koentjaraningrat divides theory into three class, namely 1). Theory in a belieforiented approach. 2). Theories relating to humans to supernatural spirits. 3). A theory is oriented towards religious ceremonies (Koentjaraningrat, 1980). Besides that, religious theory based on Van Gennep's assumptions addresses the transitional rituals or rites in people's lives.

Transitional ceremonies have a protective function for the community as a whole reducing the negative influence of travel between groups, roles or status. Van Gennep identifies internal structures, transitional ceremonies into three phases, namely rites of separation, a rite of threshold and rite of aggregation (Hockey, 2002).

Functionalism theory views religion in terms of aspects of experience as transcending a number of events that involve trust and responses to something beyond human reach. Because knowledge does not succeed in providing the necessary means of adaptation or adjusting mechanisms thus, the function of religion is to open up the horizons of the challenges of the outside world that are not accessible to the human mind.

\subsection{Confidence factors of Kaharingan Hindu}

Putra (1988) \& Riwut (2003), Kaharingan Hindus strongly believe in the existence of spirits, even though someone has died the spirit remains with the family who is still alive. If the Nyorat spirit ceremony has not yet been implemented, it will always follow his family, besides that, whatever he does will always be followed, meaning that he considers himself still living with his family, therefore his spirit will always disturb. Based on the assumption Van Gennep discusses transitional rites or rituals in people's lives. The transitional ceremony has a protection function for the community as a whole to reduce the bad influence of inter-group travel, based on the information above, the Kaharingan Hindus can hold Nyorat ceremonies, even laying the dead body for thirty days at the funeral home before being offered. This was done by them with the aim that the spirit of the deceased person can get to heaven and be able to unite with his family immortal by the Nyorat ceremony. There are several purposes for the first Nyorat ceremony. Spirit/liau will get a new place and separate from the family that is still alive. Second, the bereaved family will be able to escape from unfortunate/ambun rutas matei and will remain calm, happiness and balance that have been lost due to death among the bereaved family. Besides the above, it was also the reason they carried out the Nyorat ceremony because it was necessary to prepare a new place for the dead body/Pambak and the facilities needed for the ceremony such as sacrificial animals and the right time for the ceremony.

Death is an event that often happens around us. This is because humans are always immersed in worldly pleasures, even forgetting that there is something called death. We often ignore that the born must die etymologically the word death comes from the word "die" which means it has lost his life, does not live anymore while death means dead matter (KBBI, 1999). Based on the meaning of the dead word, it can be described that death is the process of separating the soul from the rough body. Death is a starting point for a better new life. Death does not put an end to one's personality and consciousness, and a process to open the gateway to a better life (Siwananda, 2005). A similar thing was also conveyed by Aryana (2006), that death is also actually a bridge for humans to escape from the limitations of rough bodies (stulasarira). Death is also the gate to enter the subtle realm (sukmasarira). Indeed death is the path that every living thing will pass through its evolutionary process.

Based on the description above with the Nyorat ceremony as a bridge for the spirit towards a place that has been prepared by the Almighty to return to it according to someone's promise before being born into the world will experience the process of birth, life and death as a way to return to origin merged with Ranying Hatalla Langit, Sang Hyang Widhi Wasa forever.

Riwun, Yadnyawati, I. A. G., \& Yasa, I. W. S. (2019). Nyorat ceremony of Hindu Kaharingan adherents: Telawang District, East Kotawaringin Regency. International Journal of Linguistics, Literature and Culture, 5(3), 1 -8. 


\subsection{Factors of fear of shit}

Shit/ambun rutas matei according to the belief of Hindus that Kaharingan is caused by death. If bad luck/ambun rutas matei is not removed or released from within his family this can cause a long time of grief, to overcome this effort that can be carried out by the Kaharingan Hindus by carrying out the Nyorat ceremony. According to Pisur Darkun, the task of the life of the ambun rutas matei/bad luck caused by someone's death will cause the family to carry out a funeral ceremony called Nyorat ceremony. The purpose of releasing pesky/ambun rutas matei so that the bereaved family can be released from distress and regain peace and the family will feel free to carry out daily activities including worshiping God.

\subsection{Religious social factors}

In the Nyorat ceremony, there needs to be a good relationship between the two, because all living things in the world always side by side with each other and help each other work well together, to carry out work activities. Humans as religious social beings will always be aware of ritual ceremonies and one of the ritual ceremonies carried out by Hindu Kaharingan people in Sebabi village, Telawang District, East Kotawaringin Regency is a Nyorat ceremony. In the process of implementing the Nyorat ceremony, there is always a facilities ceremony needed so that the ceremony can run smoothly and there is no need for a lack of cooperation between the family and the community around them. With the existence of a cooperative relationship between one and the other indirectly established a cooperative relationship, help each other and togetherness (Sivananda, 2005; Sulang \& Filosofi (2011).

In the opinion of Pisur Senan Nyorat ceremony can take place well if there is cooperation with close family, relatives, and community in the area. at the location where the research is now a habit or tradition from now until now is always a mutual cooperation attitude to help each other both from family and other communities who all support Nyorat ceremony nets and vice versa what if there are also natural disasters, so that other parties also do the same thing as that. Customary habits that are always carried out by the community are very social and always obey the rules that exist during the implementation of Nyorat. This means that until the end of the ceremony the entire family and the closest people always come to help both in the work and the preparation of the ceremony, everything is done together so that it is well heard, even though it has adopted other religions and still respects its forefathers.

\subsection{Economic factors}

Economics is a very important thing in people's lives, therefore the economy is also very supportive of the Nyorat ceremony. If there is an economic balance, any activity cannot be carried out properly and perfectly. In Sebabi village, Telawang District, East Kotawaringin Regency, which is the location of the research site, the Nyorat ceremony is always held depending on the ability of the family. This means that the size of the sacrifice given to the spirit of a deceased person is left entirely to the family, according to their sincerity and sincerity. For example, like sacrificial animals, there are chickens, pigs, and other offerings as a compliment, the animal is not assessed from large or small, but in the ritual used is the function of the blood, to reward the refrigerate family and others.

Economics is an important thing but in the implementation of Nyorat ceremony can be done by agreement with other families to establish working relationships with the term (handep). It means holding cooperation to help each other by giving money or think needed for the ceremony, but when the family needs it again, they will pay off as much as those brought at that time and trust each other with the agreed upon promises before.

When viewed from the data of the village head and the head of the Sebabi village group assembly, there are still many people who are Hindu Kaharingan and even young and children and always adhere to very thick traditional customs. This means that there are no changes that are visible and still remain as before, both the implementation procedures and customs and culture. In terms of education, especially those who are Hindu Kaharingan religious, they are still lacking, this is due to the limited ability of their parents to send their children to school is still lacking in financial terms, but they are able to maintain the Nyorat ceremony as before. This means that they continue to uphold the ethics of society and the state.

\subsection{Affection factor for the spirit of the deceased person}

The Nyorat ceremony for Kaharingan Hindus is a final tribute addressed to families who have passed away. According to the Hindu Kaharingan the implementation of the Nyorat ceremony caused the relationship between the 
spirit of a person who had died and living family to be separated, both outwardly and inwardly. The goal is that in carrying out daily activities there are no restrictions or obstacles that afflict the bereaved family, even though there are other religious families who will get the same thing. For them, there is no difference. The important thing is the feeling of affection and deep love, both towards the family and other people around him.

This was evident when the Nyorat ceremony took place after the corpse was buried for thirty days in the funeral home, all the families expressed their condolences to the grieving family. They came to help with anything that could be done even though those present were not all Hindus. When viewed from the concept of divinity in the teachings of Hinduism carefully, it is clear that God is omnipotent and the almighty, omniscient, unthinkable, sunya (empty) and so on. Basically humans are not able to reach the mind of God because of the limitations of the man himself, but on the other hand devotion to the Creator (God) is very high, giving rise to selfishness in each individual. Selfishness arises because the feeling of wanting to get closer to the Creator through a purely long-time spiritual path creates material desires. This desire raises restrictions created by man himself. Humans classify things materially and give names with the words nista (small), madya (medium), and utama (big). Even though it is an interpretation and opinion that is very wrong when viewed from a spiritual context. In the Bhagawad Gita XII.

The use of spells Mantra in the implementation of religious ceremonies to increase confidence in the approach to self towards Ida Sang Hyang Widhi Wasa (God). Mantra means the ceremony that comes out of the mind (manah) and the mind is a channel forming a form or form that can be imagined. The entire verse of the Sruti scriptures is generally called a mantra which covers the entire book of Samhita (Vedic Chess). Brahmana, Aranyaka, and the books Itihasa (Ramayana and Mahabharata) are included in the Bhagawadgita book. In Bali, every poem in Sanskrit is called a mantra, while puja prayers that use Balinese are called sehe. In the belief of the Hindu Kaharingan in Central Kalimantan, the Pisur in performing ritual ceremonies also always use the sacred language Ranying Hatalla Langit, which is called Sangiang (the natural language of the gods).

In this case, the Hindu Kaharingan prayed to get closer to the Creator. It is one of the ways that is done, both to the spirit of someone who has died and a spirit that cannot be seen with the eye. This means that the way did is sincere offerings and without expecting rewards, that is giving offerings in the form of offerings with the aim that the evil spirit will not interfere. In the spirit burial procession, a deceased person will also be able to accept such a situation. Thus, the implementation of the Nyorat ceremony can go well and there are no obstacles to the family of mourning.

The meaning of the pronunciation of the mantra by Pisur when narrating the journey of the spirit of the deceased is so that he knows that he will return to Ranying Hatalla Langit and will never return to the world. In the term local language, it is called panting batu dia tau lulang luli, This means that death is the last journey back to the Creator and will not return to this world forever. When viewed from the teachings of Hinduism such a process includes the process of returning from the panca maha bhuta namely the bhuana agung and bhuana alit will be reunited to their origin.

\subsection{Psychological religious implications, socio-cultural and economic}

The religious implications of the Hindu Kaharingan community in Sebabi village, Telawang District, East Kotawaringin Regency are related to (1). The belief from generation to generation, if the Nyorat ceremony is not carried out it will lose the meaning and purpose of the ceremony. (2). Psychic implications require cooperation to help each other so that the Nyorat ceremony is carried out. (3). The socio-cultural implications of intervening in support of the ceremony, and (4) economic implications also strongly supported the Nyorat ceremony to run smoothly and there was no matter after the end of the ceremony, especially for the deceased's closest family.

\section{Conclusion}

Nyorat ceremony is a series of funeral ceremonies carried out by Hindu Kaharingan people in Sebabi village, Telawang sub-district, East Kotawaringin Regency which was carried out after a dead person was buried for thirty days in a funeral home and was recently refurbished. The Nyorat ceremony as the executor consisted of two people namely Pisur with their respective duties, by the death section, but both of them played together and worked together. This is done in the hope that the Pisur will carry out his duties properly and will not disturb each other and concentrate fully. This can also be done because at the time of the Nyorat ceremony the Pisur performed their duties based solely on memory and until now there is still no manual for the Nyorat ceremony. With facilities that must be

Riwun, Yadnyawati, I. A. G., \& Yasa, I. W. S. (2019). Nyorat ceremony of Hindu Kaharingan adherents: Telawang District, East Kotawaringin Regency. International Journal of Linguistics, Literature and Culture, 5(3), 1 -8. 
prepared by them will require good cooperation in the family so that the ceremony gets a good reward and gets good and calm of life after the end of the Nyorat ceremony takes place. Based on this, Hindus in Sebabi Kacamatan Telawang village can preserve a local culture which is a priceless ancestral wealth for human life because their beliefs are very strong.

Conflict of interest statement and funding sources

The authors declared that they have no competing interest. The study was financed by independent funding.

Statement of authorship

The authors have a responsibility for the conception and design of the study. The authors have approved the final article.

\section{Acknowledgments}

The authors would like to thank the editor and reviewer of the IJLLC for their valuable time, support and advice in completing the present paper. 
References

Adi, T. N. (2008). Identitas Kultural dan Televisi Lokal (Studi Tentang Konstruksi dan Representasi Identitas Kultural dalam Tayangan Banyumas TV) (Doctoral dissertation, Tesis: Program Pascasarjana Universitas Sebelas Maret, Surakarta).

Aryana, P.J. (2008). Atma Prasangsia, Memahami Kematian dalam Tradisi Budaya Bali. Denpasar: Baliaga.

Badudu, Y., \& Zain, S. M. (1994). Kamus umum bahasa Indonesia. Pustaka Sinar Harapan.

Dhavamony, M. (1995). Fenomenologi agama. Kanisius.

Hockey, J. (2002). The importance of being intuitive: Arnold van gennep's the rites of passage. Mortality, 7(2), 210217. https://doi.org/10.1080/135762702317447768

Kaler, I. G. K. (1993). Ngaben: mengapa mayat dibakar? (No. 3). Yayasan Dha

Koentjaraningrat, R. M. (1980). Javanese terms for god and supernatural beings and the idea of power. Man, meaning and history: essays in honour of HG Schulte Nordholt, 127-39.

Koentjaraningrat, R. M. (1980). Javanese terms for god and supernatural beings and the idea of power. Man, meaning and history: essays in honour of HG Schulte Nordholt, 127-39.

Mutar, R.B. (2005). Petunjuk Penguburan Umat Hindu Kaharingan. Kanwil Depag, Propinsi Kalimantan Tengah.

Putra, I. G. (1988). Panca yadnya. Yayasan Dharma Sarathi.

Rahmawati, D. E. (2008). Resepsi cerita rakyat bledhug kuwu. Skripsi. Program Sarjana Universitas Negeri Semarang, Semarang.

Riwut, T. (2003). Maneser panatau tatu hiang: menyelami kekayaan leluhur. Palangka Raya: Pustaka Lima.

Sivananda, S. S. (2005). Apa Yang Terjadi Pada Jiwa Setelah Kematian. Surabaya: Paramita.

Sivananda, S. S. (2005). La Bhagavad Gita. Edizioni Mediterranee.

Sulang, K., \& Filosofi, M. A. A. S. (2011). Budaya Dayak: Permasalahan dan alternatifnya. Malang: Bayumedia Publishing.

Riwun, Yadnyawati, I. A. G., \& Yasa, I. W. S. (2019). Nyorat ceremony of Hindu Kaharingan adherents: Telawang District, East Kotawaringin Regency. International Journal of Linguistics, Literature and Culture, 5(3), $1-8$. https://doi.org/10.21744/ijllc.v5n3.620 


\section{Biography of Authors}

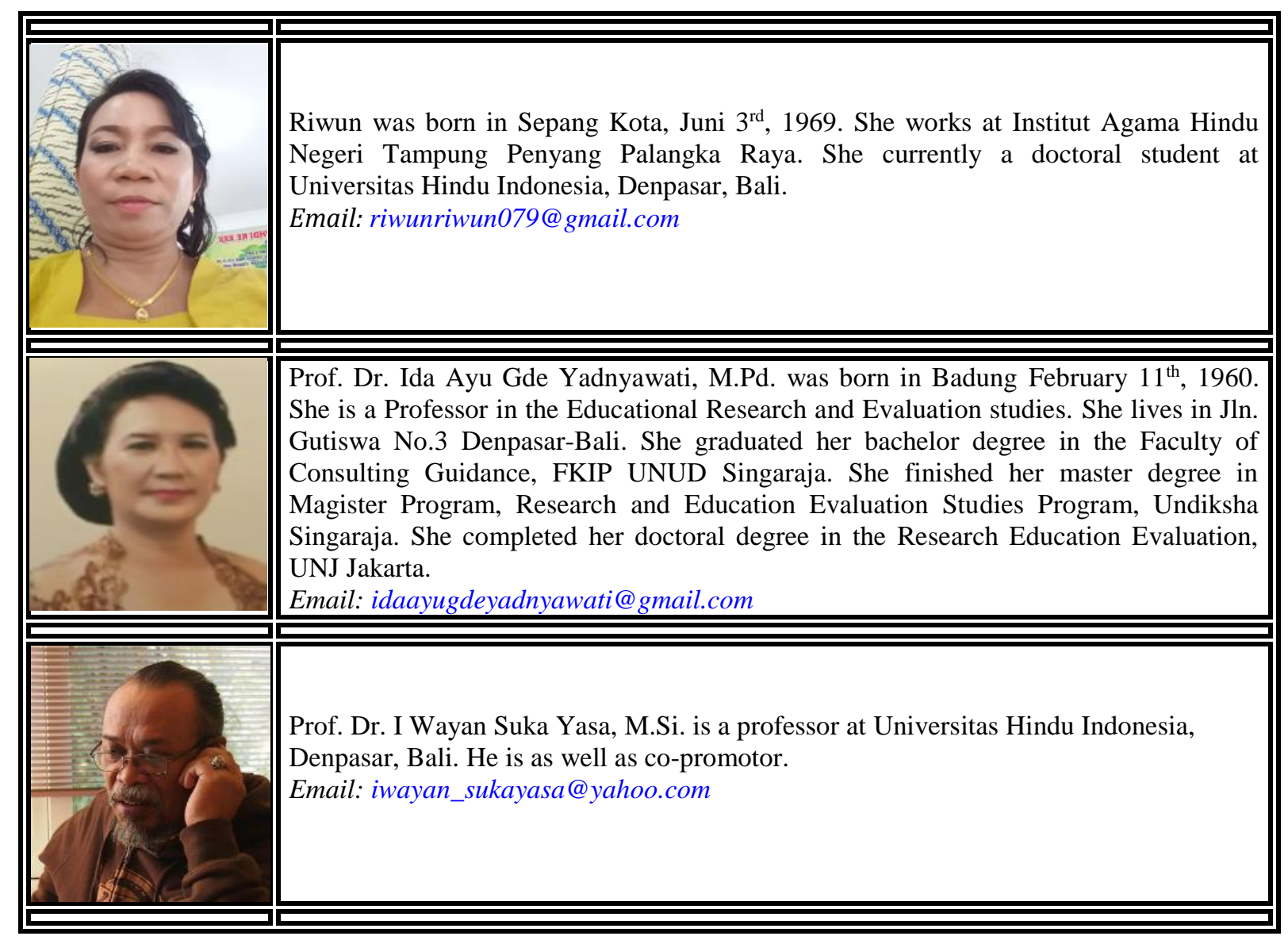

